\title{
Synthesis of 1,8-Naphthyridine Derivatives under Ultrasound Irradiation and Cytotoxic Activity against HepG2 Cell Lines
}

\author{
N. S. Ahmed, ${ }^{1,2}$ K. O. AlFooty, ${ }^{1}$ and S. S. Khalifah ${ }^{1}$ \\ ${ }^{1}$ Chemistry Department, Faculty of Science, King Abdulaziz University, P.O. Box 80203, Jeddah 21589, Saudi Arabia \\ ${ }^{2}$ Medicinal Chemistry Department, National Research Center, Dokki, Cairo 12622, Egypt \\ Correspondence should be addressed to N. S. Ahmed; nesreen69eg@yahoo.com
}

Received 4 December 2013; Revised 27 January 2014; Accepted 27 January 2014; Published 12 March 2014

Academic Editor: Angelo de Fatima

Copyright (c) 2014 N. S. Ahmed et al. This is an open access article distributed under the Creative Commons Attribution License, which permits unrestricted use, distribution, and reproduction in any medium, provided the original work is properly cited.

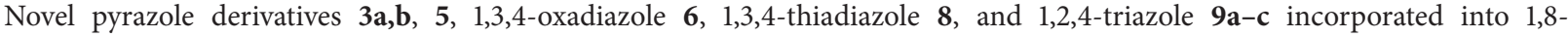
naphthyridine have been synthesized using the versatile synthon 2-(2,7-dimethyl-1,8-naphthyridin-4-yloxy) acetohydrazide 1. An improvement in rates and yields was observed when the reactions were carried out under ultrasonic irradiation compared with the classical synthesis. The newly synthesized compounds were evaluated for HepG2 cell growth inhibition. The results obtained revealed that the tested compounds possess inhibitory effect on the growth of HepG2 liver cancer cells. The results were compared to doxorubicin $(\mathrm{DOX})$ as a reference drug $\left(\mathrm{IC}_{50}: 0.04 \mu \mathrm{M}\right)$. Compounds $\mathbf{9 b}$ showed the highest inhibition activity against HepG2 cell line $\left(\mathrm{IC}_{50}: 0.048 \mu \mathrm{M}\right)$ among all tested compounds.
\end{abstract}

\section{Introduction}

Naphthyridine derivatives have received significant attention due to their exceptionally broad spectrum of biological activity. For example 1,8-naphthyridine derivatives have promising medicinal properties, including anti-HIV [1], anticancer [2], anti-inflammatory [3], antimalarial [4], antibacterial [5], antiprotozoals [6], antimycobacterial [7], and antiplatelet [8]. In addition 1,8-naphthyridine derivatives were found to display cytotoxic activity against murine P388 leukemia cell line when changes were carried out at N-1 and C7 positions $[9,10]$. Moreover, it was recently found that 1,8-naphthyridine derivative vosaroxin (formerly SNS-595, AG-7352, AT-3639, or Voreloxin) (Figure 1) was found to have potential anticancer activity; it is currently subjected to clinical development. This drug is believed to exert its action via topoisomerase II inhibition [11]. Topoisomerase II is one of the well-known targets for antitumor agents like doxorubicin, etoposide, ellipticine, and amsacrine [12]. We have reported in a previous article that 1,8-naphthyridine substituted with Mannich bases, $N$ - $\beta$-glycosides, and Schiff's bases showed potent cytotoxic activity against HepG2 cell line [13].
On the other hand, an important class of heterocyclic compounds such as pyrazoles [14,15], 1,2,4-triazole derivative [16],1,3,4-thiadiazoles [17], and 1,3,4-oxadiazoles [18] showed a remarkable anticancer effect [14-18]. Based on these observations it was of interest to incorporate the 1,8-naphthyridine ring system into the abovementioned nitrogen, sulphur, and oxygen heterocyclic systems in one molecule in a trial to obtain a new target and product of dual mode of biological function. The application of ultrasound in synthetic organic chemistry became more and more interesting. "Sonochemistry" is a new trend in organic chemistry, offering a versatile and pathway for a large variety of syntheses. Therefore, a large number of organic reactions can be carried out under ultrasonic irradiation in high yields, short time, and mild conditions [19-24].

As an extension of our efforts directed towards development of convenient synthetic approaches for the construction of biologically active heterocycles and as a part of growing interest in sonochemistry [25-27], our strategy is to develop a facile sonochemical synthesis and high yield procedure to prepare some novel 1,3,4-oxadiazole, 1,3,4-thiadiazole, 1,2,4triazole, and pyrazole incorporated into 1,8-naphthyridine 


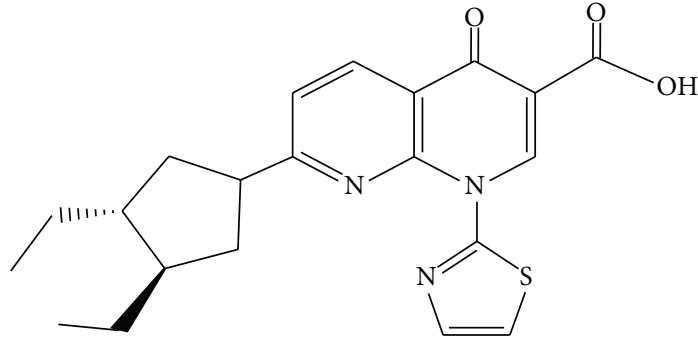

FIGURE 1: Vosaroxin.

and the findings of their biological activities in suppressing the growth of HepG2 liver cancer cells.

\section{Results and Discussion}

2.1. Chemistry. The starting material, namely, 2-(2,7-dimethyl-1,8-naphthyridin-4-yloxy) acetohydrazide 1 [27], allowed to react with the diketone, namely, acetylacetone and benzoylacetone, under ultrasound irradiation at $65^{\circ} \mathrm{C}$ (Scheme 1). The IR spectra 2-((2,7-dimethyl-1,8- naphthyridin-4-yl)oxy)-1-(3,5-dimethyl-1H-pyrazol-1-yl) ethanone $\mathbf{3 a}$ revealed the disappearance of $-\mathrm{NHNH}_{2}$ bands of hydrazide and showed only one band at $1674 \mathrm{~cm}^{-1}$ characteristic for amidic CO group. ${ }^{1}$ HNMR for compound $\mathbf{3 a}$ showed the disappearance of the broad singlet signals from $\delta$ 3.99 and 9.28 corresponding to $\mathrm{NH}_{2}$ and $\mathrm{NH}$ protons, respectively, in acid hydrazide $\mathbf{1}$ and the appearance of three singlet signals due to 2 methyl groups and $\mathrm{CH}$ pyrazole at $\delta 1.69,2.00$, and 6.47 , respectively, beside the original methyl groups, $3 \mathrm{CH}$ - of naphthyridine and the methylene protons. The mass spectrum of this compound showed molecular ion peak $\mathrm{m} / z 310$ consistent with its molecular formula $\mathrm{C}_{17} \mathrm{H}_{18} \mathrm{~N}_{4} \mathrm{O}_{2}$. Also, reaction of 1 with excess ethylacetoacetate under ultrasound irradiation at $60^{\circ} \mathrm{C}$ for $10 \mathrm{~min}$ gives only one isolable uncyclized product identified as ethyl-3-(2-(2-(2,7-dimethyl-1,8-naphthyridin-4yloxy)acetyl)hydrazono)butanoate 4 (Scheme 1). The structure of compound $\mathbf{4}$ was confirmed on the basis of its elemental and spectral data. The IR spectrum for 4 showed str. absorption band at $3200 \mathrm{~cm}^{-1}$ characteristic for $\mathrm{NH}$ and strong absorption band at $1722 \mathrm{~cm}^{-1}$ for $\mathrm{CO}$ of ester. ${ }^{1} \mathrm{HNMR}$ of the compound 4 revealed one $\mathrm{D}_{2} \mathrm{O}$ exchangeable signal at $\delta 9.05$ due to $\mathrm{NH}$, triplet and quartet signals at $\delta 1.32$ and 4.24 for ethyl group, and two singlet signals at $\delta 2.15$ and 3.40 for new methyl and methylene groups, respectively. Upon increasing the time of the foregoing reaction to $25 \mathrm{~min}$ under the same conditions the cyclized product, 1-(2-(2,7-dimethyl-1,8-naphthyridin4-yloxy)acetyl)-3-methyl-1H-pyrazol-5(4H)-one 5 ,was obtained (Scheme 1).

The structure of the new pyrazolone 5 was confirmed on the basis of its elemental analysis and IR, ${ }^{1} \mathrm{HNMR},{ }^{13} \mathrm{CNMR}$, and mass spectral data, and its ${ }^{1} \mathrm{HNMR}$ revealed the disappearance of the two singlet signals from $\delta 3.99$ and 9.28 corresponding to $\mathrm{NH}_{2}$ and $\mathrm{NH}$ protons and new two singlet
TABLE 1: Synthesis of pyrazole derivatives $\mathbf{3 a - b}, \mathbf{4}$, and $\mathbf{5}$ under both ultrasonic irradiation and conventional method.

\begin{tabular}{lcccc}
\hline \multirow{2}{*}{ Compound } & \multicolumn{2}{c}{ Ultrasonic irradiation } & \multicolumn{2}{c}{ Conventional } \\
& Time (min.) & Yield \% & Time (min.) & Yield \% \\
\hline 3a & 10 & 98 & 60 & 93 \\
$\mathbf{3 b}$ & 10 & 97 & 60 & 91 \\
$\mathbf{4}$ & 10 & 93 & 60 & 87 \\
$\mathbf{5}$ & 25 & 96 & 180 & 83 \\
\hline
\end{tabular}

signals at $\delta 2.17$ and 3.39 for methyl group and $\mathrm{CH}_{2}$-pyrazole, respectively.

To find the specific effect of ultrasound on this reaction, all previously mentioned reactions were carried out under the same conditions in absence of ultrasound irradiations (Table 1). The data cited in Table 1 showed that the reaction time increased and the yields of the products decreased in absence of ultrasonic irradiation. Thus, the ultrasound irradiation was found to have beneficial effect on the synthesis of the pyrazole derivatives.

Furthermore a new series of 4-((oxymethyl)heterocyclo) 2,7-dimethyl-1,8-naphthyridines were synthesized under ultrasound irradiation. These compounds were obtained by reaction of 1 with $\mathrm{CS}_{2}$ in the presence of ethanolic $\mathrm{KOH}$ (Scheme 2).

Upon subjecting the reaction mixture to ultrasonic irradiation at $65^{\circ} \mathrm{C}$, the elemental analysis and spectral data of the reaction product were compatible only with the corresponding oxadiazole derivative $\mathbf{6}$. IR spectra revealed that weak absorption band at $3200 \mathrm{~cm}^{-1}$ correspond to $\mathrm{NH}$, and at $1293 \mathrm{~cm}^{-1}$ band due to $\mathrm{C}=\mathrm{S}$ group. On the other hand the acid hydrazide 1 with excess $\mathrm{CS}_{2}$ in ethanolic $\mathrm{KOH}$ was subjected to ultrasound irradiation at room temperature; it gave the dithiocarbazate potassium salt 7 (Scheme 2). The IR spectra for 7 showed band due to $\mathrm{NH}$ at $3132 \mathrm{~cm}^{-1}, \mathrm{C}=\mathrm{O}$ amidic at $1686 \mathrm{~cm}^{-1}$, and $\mathrm{C}=\mathrm{S}$ at $1291 \mathrm{~cm}^{-1}$. The dithiocarbazate potassium salt 7 was added to concentrated $\mathrm{H}_{2} \mathrm{SO}_{4}$ at $0^{\circ} \mathrm{C}$ and then subjected to ultrasound irradiation (Scheme 2); it afforded 5-((2,7-dimethyl-1,8naphthyridin-4-yl)oxy)-methyl)1,3,4-thiadiazole-2-thiol $\mathbf{8}$ methyl. The IR spectra showed the disappearance of $\mathrm{NH}$ band at $3200 \mathrm{~cm}^{-1}$ and new band at $2352 \mathrm{~cm}^{-1}$ for $\mathrm{SH}$ was observed. The ${ }^{1} \mathrm{HNMR}$ spectrum showed only one $\mathrm{D}_{2} \mathrm{O}$ exchangeable signal due to $\mathrm{SH}$ at $\delta$ 10.5. Its mass spectrum revealed a peak corresponding to the molecular ion $\mathrm{m} / z$ 304. Furthermore, reaction of the potassium salt 7 with hydrazinehydrate in ethanol under ultrasound irradiation at $60-65^{\circ} \mathrm{C}$ afforded only one isolable product (as examined by TLC) identified as 4-amino-5-((2,7-dimethyl1,8-naphthyridin-4-yloxy)methyl)-4H-1,2,4-triazole-3-thiol 9a (Scheme 2); under the same reaction conditions the pot salt 7 allowed to react with phenyl hydrazine and methyl hydrazine; it gave the corresponding aminophenyl and aminomethyltriazole derivative $\mathbf{9 b}$ and 9c (Scheme 2). All structures were established according elemental analysis and spectral data. The IR spectra of 9a showed the disappearance of carbonyl group of potassium salt at $1660 \mathrm{~cm}^{-1}$ and two 


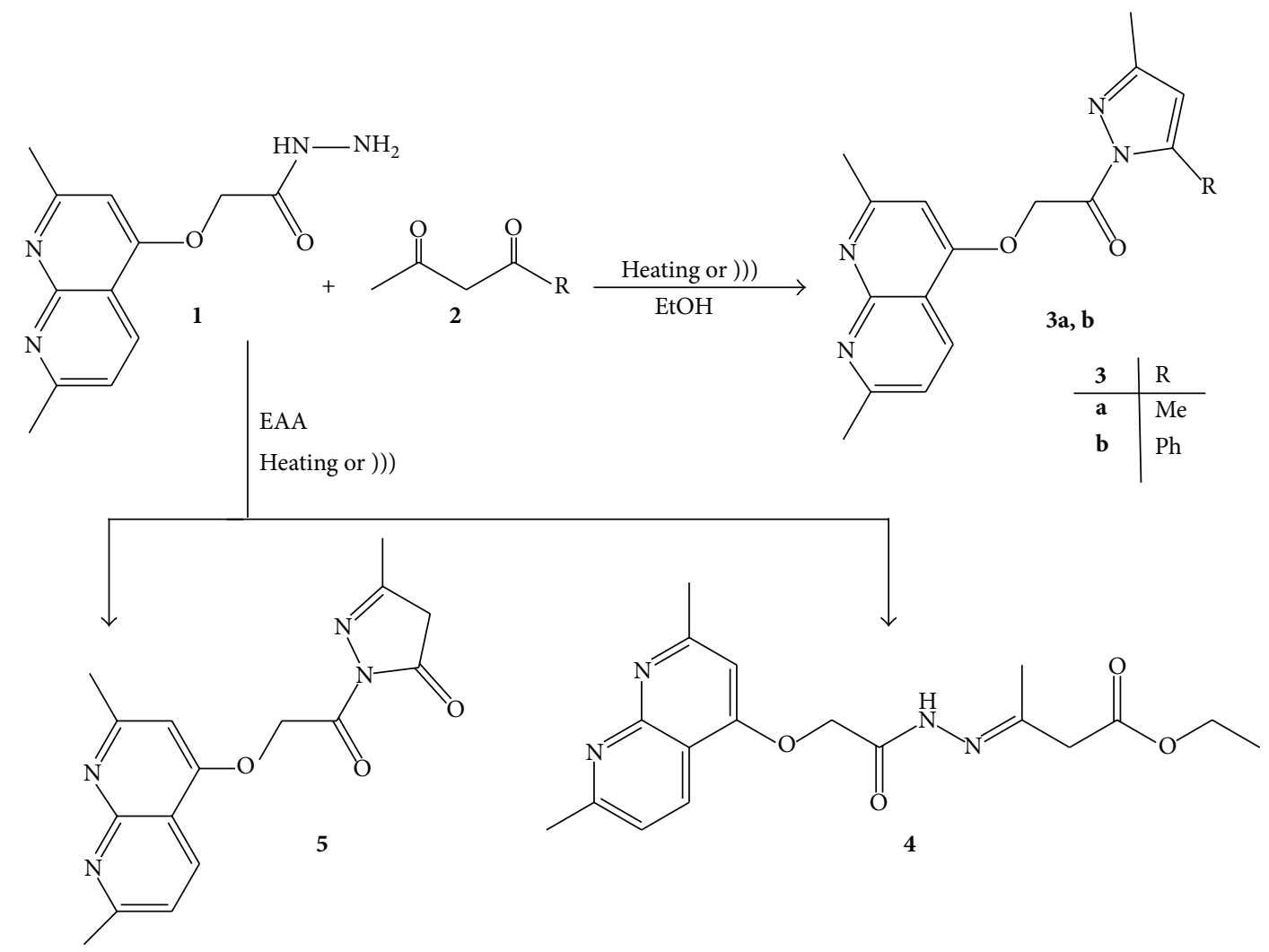

SCHEME 1

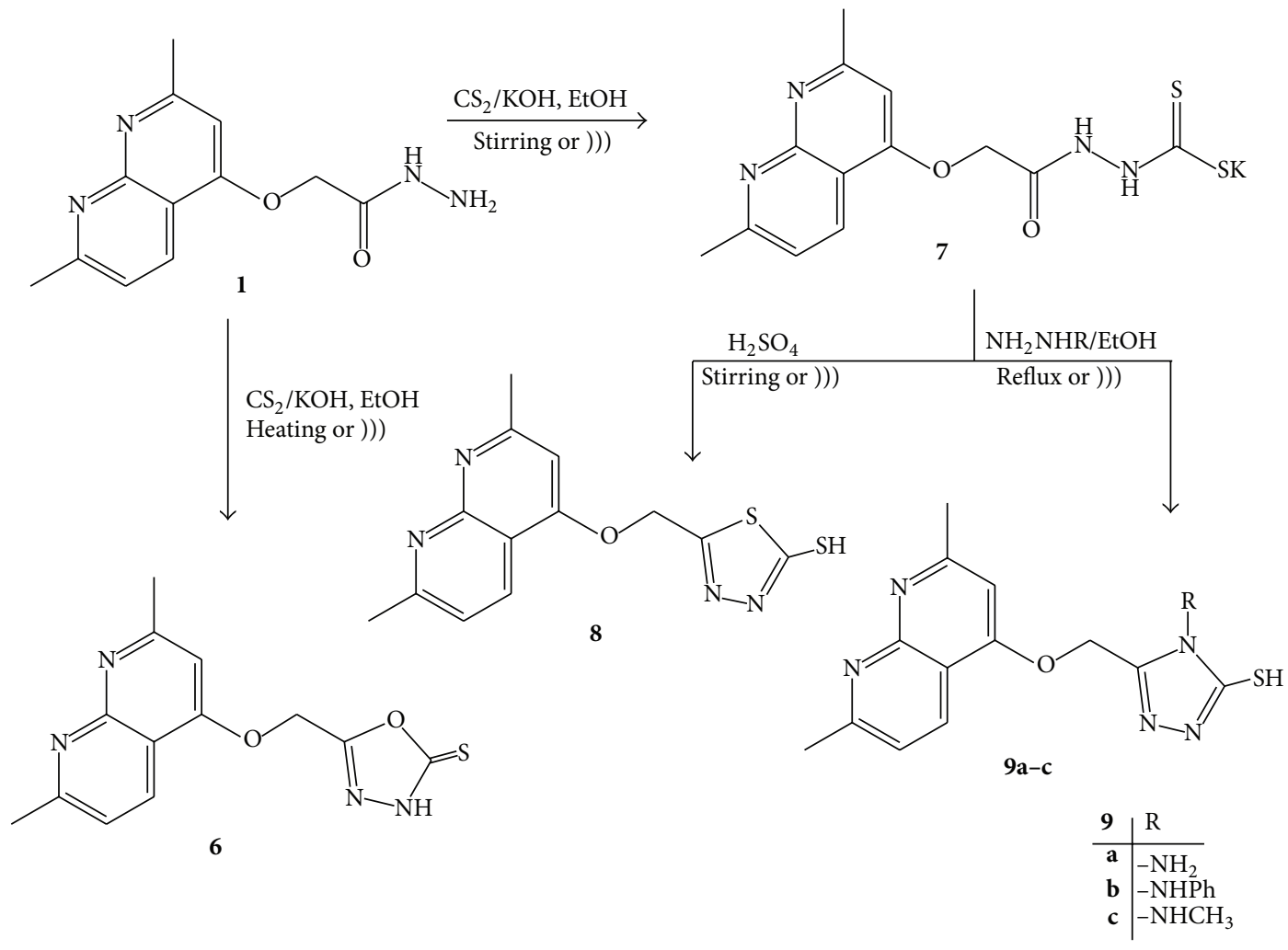

Scheme 2 
TABLE 2: Synthesis of 1,3,4-oxadiazole 6, 1,3,4-thiadiazole 8 , and 1,2,4-triazole $\mathbf{9 a - c}$ derivatives under ultrasonic irradiation and conventional method.

\begin{tabular}{lcccc}
\hline \multirow{2}{*}{ Compound } & \multicolumn{2}{c}{ Ultrasonic irradiation } & \multicolumn{2}{c}{ Conventional } \\
& Time (min.) & Yield \% & Time $(\mathrm{h})$ & Yield \% \\
\hline $\mathbf{6}$ & 45 & 91 & 24 & 76 \\
$\mathbf{7}$ & 25 & 96 & 8 & 93 \\
$\mathbf{8}$ & 10 & 89 & 2 & 73 \\
9a & 15 & 96 & 4 & 83 \\
9b & 15 & 91 & 3 & 77 \\
9c & 15 & 88 & 3 & 69 \\
\hline
\end{tabular}

new stretching absorption bands at 3151 and $3244 \mathrm{~cm}^{-1}$ corresponding to $\mathrm{NH}_{2}$ group. ${ }^{1} \mathrm{HNMR}$ for 9a revealed two $\mathrm{D}_{2} \mathrm{O}$ exchangeable singlet signals due to $\mathrm{NH}_{2}$ and $\mathrm{SH}$ protons at $\delta 2.91$ and 13.55, respectively. Time of reactions and yield are shown in Table 2. It is shown from this table that the ultrasound technique reduced the time of the reactions from several hours to minutes and improved the yield from $69-83 \%$ (under conventional conditions) to $88-96 \%$.

Generally, ultrasound showed beneficial effect on the synthesis of some novel pyrazoles, 1,3,4-oxadiazole, 1,3,4-thiadiazole, and 1,2,4-triazole incorporated into 1,8-naphthyridine which decreases the time of the above reactions from several hours in conventional procedure to few minutes with high yield under ultrasound irradiation. The improvement induced by ultrasound in the abovementioned reaction can be attributed to the well-established theory for the cavitation. These reactions according to sonochemical classification of Cabello et al. [28] and Ikawa et al. [29] are considered as false sonochemistry type in which cavitation effect provides the mechanical energy for all subsequent chemical reactions, including bond scission induced by viscous frictional forces.

2.2. Pharmacology. Preliminary screening showed that all selected compounds exhibited a moderate to strong growth inhibition activity on the tested cell line $\left(\mathrm{IC}_{50}\right.$ : $0.048-$ $0.091 \mu \mathrm{M})$ concentrations in comparison to the traditional anticancer drug doxorubicin (DOX). It can be deduced from the results cited in Table 3 that compound $\mathbf{9 b}$ showed a growth inhibition activity quite similar to that observed to DOX. The pronounced activity might be due to the presence of N-aminophenyltriazole attached to (2,7-dimethyl-1,8naphthyridine-4-yloxy) methyl moiety [30].

\section{Conclusion}

We have synthesized a class of novel substituted pyrazoles, 1,3,4-oxadiazole, 1,3,4-thiadiazole, and 1,2,4-triazole incorporated into 1,8-naphthyridine nucleus under both sonication and classical conditions. In general, improvements in rates and yield of the reactions are observed when reactions were carried out under sonication compared with classical condition. The cytotoxicity screening of the new compounds revealed that the selected compounds showed reasonable
TABLE 3: $\mathrm{IC}_{50}(\mu \mathrm{M})$ of some selected new compounds against liver cancer cell line HepG2.

\begin{tabular}{lc}
\hline Compounds & $\mathrm{IC}_{50}(\mu \mathrm{M})$ \\
\hline DOX & 0.04 \\
3a & 0.071 \\
3b & 0.064 \\
$\mathbf{5}$ & 0.091 \\
$\mathbf{6}$ & 0.067 \\
$\mathbf{8}$ & 0.063 \\
9a & 0.058 \\
9b & 0.048 \\
9c & 0.067 \\
\hline
\end{tabular}

antitumor activity against HepG2 cancer cell line in comparison to the traditional anticancer drug DOX. Among all tested compounds, $\mathbf{9 b}$ was found to have the highest inhibitory activity against HepG2 cell line with $\mathrm{IC}_{50}$ value $0.048 \mu \mathrm{M}$.

\section{Experimental}

\subsection{Chemistry}

4.1.1. General. All melting points were measured on a MelTemp apparatus and were uncorrected. Thin layer chromatography (TLC) was performed on aluminum silica gel $60 \mathrm{~F}_{254}$ (E-Merk). The spots were detected by iodine and UV light absorption. IR spectra were recorded on a FTIR, Perkin Elmer SP 100 spectrometer. ${ }^{1} \mathrm{H}$ NMR and ${ }^{13} \mathrm{C}$ NMR spectra were recorded on Burker WM 350 and $600 \mathrm{MHz}$ spectrometers using TMS (0.00 ppm). Chemical shift $(\delta)$ is given in ppm relative to the signal for TMS as standard and coupling constant in $\mathrm{Hz}$. Mass spectra were recorded on a Shimadzu GCMS-QP 1000 EX mass spectrometer at 70 e.v. Sonication was performed by Daihan (Wiseclean, D-40 kHz).

(1) Synthesis of 2-((2,7-Dimethyl-1,8-naphthyridin-4-yl)oxy)-1(3,5-substituted-1H-pyrazol-1-yl)ethanone $(\mathbf{3 a}, \boldsymbol{b})$

Method A: Silent Reactions. A mixture from acid hydrazide 1 (16 $\mathrm{mmol}$ ) and appropriate 1,3-diketone, namely, acetylacetone and benzoylacetone $(65 \mathrm{mmol})$ in absolute ethanol $(10 \mathrm{~mL})$, was heated at $100^{\circ} \mathrm{C}$ in a steam for a suitable time as examined by TLC. Then Cooled and treated with pet. ether. The solid precipitate formed was collected by filtration, washed with pet. ether, and dried. Recrystallization, from ethanol, afforded compounds $\mathbf{3 a} \mathbf{a} \mathbf{b}$.

Method B: Sonicated Reactions. In a $50 \mathrm{~mL}$ Erlenmeyer flask a mixture of acid hydrazide $1(16 \mathrm{mmol})$ and appropriate 1,3-diketone, namely, acetylacetone and benzoylacetone $(65 \mathrm{mmol})$, in absolute ethanol $(10 \mathrm{~mL})$, was subjected to ultrasound irradiation for suitable time ( $c f$. Table 1) until the starting material was no longer detectable by TLC. All the reactions were kept at temperature $60-65^{\circ} \mathrm{C}$ (the temperature inside reaction vessel was $60^{\circ} \mathrm{C}$ ). The precipitate formed was filtered off and washed with pet. 
ether and finally recrystallized from ethanol to afford the corresponding 2-((2,7-dimethyl-1,8-naphthyridin-4-yl)oxy)1-(3,5-substituted-1H-pyrazol-1-yl) ethanone $\mathbf{3 a , b}$.

The synthesized compounds $(\mathbf{3} \mathbf{a}, \mathbf{b})$ with their physical data are listed below.

2-((2,7-Dimethyl-1,8-naphthyridin-4-yl)oxy)-1-(3,5-dimethyl1H-pyrazol-1-yl)ethanone (3a). Off-white; crystals m.p $214^{\circ} \mathrm{C}$. FTIR: $1674(\mathrm{C}=\mathrm{O}), 1619(\mathrm{C}=\mathrm{N}), 1606(\mathrm{C}=\mathrm{C}) ;{ }^{1} \mathrm{H}$ NMR $\left(350 \mathrm{MHz}, \mathrm{DMSO}-\mathrm{d}_{6}\right): \delta_{\mathrm{H}}=1.69,2.00\left(6 \mathrm{H}, 2 \mathrm{~s}, 2 \mathrm{CH}_{3}\right.$ of pyrazole), $2.46,2.51\left(6 \mathrm{H}, 2 \mathrm{~s}, 2 \mathrm{CH}_{3}\right.$ of naphthyridine), 5.54 $\left(2 \mathrm{H}\right.$, br.s, $\left.\mathrm{CH}_{2}\right), 6.08\left(1 \mathrm{H}, \mathrm{s}, \mathrm{C}_{3}-\mathrm{H}\right.$, naphthyridine $), 6.74(1 \mathrm{H}$, s, $\mathrm{C}_{4}-\mathrm{H}$, pyrazole); $7.24\left(1 \mathrm{H}, \mathrm{d}, \mathrm{C}_{6}-\mathrm{H}, J=7.8 \mathrm{~Hz}\right) ; 8.31(1 \mathrm{H}, \mathrm{d}$, $\left.\mathrm{C}_{7}-\mathrm{H}, J=7.8 \mathrm{~Hz}\right) ;{ }^{13} \mathrm{C} \mathrm{NMR}\left(150 \mathrm{MHz}, \mathrm{CDCl}_{3}\right): \delta_{\mathrm{C}}=16.24$, 21.46, 25.12, 26.98, 46.56, 91.89, 112.32, 118.42, 119.78, 135.83, 150.36, 151.69, 156.12, 161.72, 166.59, 178, 207.04; MS (m/z): 310 $\mathrm{M}^{+}$. (Found: $\mathrm{C}, 65.84 ; \mathrm{H}, 5.55 ; \mathrm{N}, 17.97 . \mathrm{C}_{17} \mathrm{H}_{18} \mathrm{~N}_{4} \mathrm{O}_{2}$ requires C, 65.79; H, 5.85; N, 18.05.)

2-((2,7-Dimethyl-1,8-naphthyridin-4-yl)oxy)-1-(5-methyl-3phenyl-1H-pyrazol-1-yl)ethanone (3b). Pale yellow crystals; m.p. $220-222^{\circ}$ C. FTIR: $1676(\mathrm{C}=\mathrm{O}) ; 1607(\mathrm{C}=\mathrm{N}) ;{ }^{1} \mathrm{H}$ NMR $\left(350 \mathrm{MHz}, \mathrm{DMSO}-\mathrm{d}_{6}\right): \delta_{\mathrm{H}}=2.07\left(3 \mathrm{H}, \mathrm{s}, \mathrm{C}_{5}-\mathrm{CH}_{3}\right), 2.42(3 \mathrm{H}$, s, $\left.\mathrm{C}_{7}-\mathrm{CH}_{3}\right), 2.55\left(3 \mathrm{H}, \mathrm{s}, \mathrm{C}_{2}-\underline{\mathrm{CH}}_{3}\right), 5.62\left(2 \mathrm{H}\right.$, br.s, $\left.\mathrm{CH}_{2}\right), 6.03$ $\left(1 \mathrm{H}, \mathrm{s}, \mathrm{C}_{3}-\mathrm{H}\right)$ and $6.92\left(1 \mathrm{H}, \mathrm{s}, \mathrm{C}_{4}-\mathrm{H}\right.$ of pyrazole $), 7.16-7.31(6 \mathrm{H}$, $\mathrm{m}, \mathrm{C}_{6}-\mathrm{H}$ and ArH's), $8.27\left(1 \mathrm{H}, \mathrm{d}, \mathrm{C}_{5}-\mathrm{H}\right) ;{ }^{13} \mathrm{C} \mathrm{NMR}(150 \mathrm{MHz}$, $\left.\mathrm{CDCl}_{3}\right): \delta_{\mathrm{C}}=16.14,21.47,25.10,46.69,112.28,118.45,119.75$, $123.80,127.00,128.62,132.29,135.81,142.88,150.30,151.59$, $155.90,161.56,166.31,178.03,207.04$; MS $(m / z): 372 \mathrm{M}^{+}$. (Found: C, 71.25; H, 5.61; N, $15.34 \mathrm{C}_{22} \mathrm{H}_{20} \mathrm{~N}_{4} \mathrm{O}_{2}$ requires $\mathrm{C}$, 70.95; H, 5.41; N, 15.04.).

(2) Ethyl-3-(2-(2-(2,7-dimethyl-1,8-naphthyridin-4-yloxy) acetyl)hydrazono)butanoate (4)

Method A: Silent Reaction. A mixture of acid hydrazide 1 (16 $\mathrm{mmol})$ with ethylacetoacetate $(65 \mathrm{mmol})$ was heated at $100^{\circ} \mathrm{C}$ in steam bath for $1 \mathrm{~h}$. After cooling, the residue obtained was treated with pet. ether and the solid product obtained was filtered off and recrystallized from ethanol; it gives the title compound 6.

Method B: Sonicated Reaction. A mixture of acid hydrazide 1 $(16 \mathrm{mmol})$ and ethylacetoacetate $(65 \mathrm{mmol})$ in $50 \mathrm{~mL}$ Erlenmeyer flask was subjected to ultrasound irradiation for suitable time ( $c f$. Table 1) until the starting material was no longer detectable by TLC. All the reactions were kept at temperature $60-65^{\circ} \mathrm{C}$ (the temperature inside reaction vessel was $60^{\circ} \mathrm{C}$ ). The precipitate formed was filtered off and washed with pet. ether and finally recrystallized from ethanol to afford the corresponding ethyl-3-(2-(2-(2,7-dimethyl-1,8naphthyridin-4-yloxy)acetyl)hydrazano)butanoate 4,), m.p. 179-180.5 C. FTIR: $3200(\mathrm{~N}-\mathrm{H})$; 1722 (C=O of ester); $1625 \mathrm{~cm}^{-1}$ (C=O amidic); ${ }^{1} \mathrm{H}$ NMR $\left(350 \mathrm{MHz}, \mathrm{CDCl}_{3}\right): \delta_{\mathrm{H}}$ $=1.32\left(3 \mathrm{H}, \mathrm{q},-\mathrm{CH}_{2} \mathrm{CH}_{3}, J=7.2 \mathrm{~Hz}\right), 2.15(3 \mathrm{H}, \mathrm{s},-\mathrm{N}=\mathrm{C}-$ $\left.\mathrm{CH}_{3}\right), 2.40,2.58\left(6 \mathrm{H}, 2 \mathrm{~s}\right.$ for $\left.\mathrm{C}_{2}-\mathrm{CH}_{3}, \mathrm{C}_{7}-\mathrm{CH}_{3}\right), 3.40(2 \mathrm{H}, \mathrm{s}$, $\left.-\mathrm{N}=\mathrm{C}-\mathrm{CH}_{2}-\mathrm{CO}\right), 4.24\left(2 \mathrm{H}, \mathrm{q},-\mathrm{CH}_{2} \mathrm{CH}_{3}, J=7.2 \mathrm{~Hz}\right), 5.63$ $\left(2 \mathrm{H}, \mathrm{s},-\mathrm{OCH}_{2} \mathrm{CO}\right), 6.26\left(1 \mathrm{H}, \mathrm{s}, \mathrm{C}_{3}-\mathrm{H}\right), 7.15\left(1 \mathrm{H}, \mathrm{d}, \mathrm{C}_{6}-\mathrm{H}\right.$,
$J=7.8 \mathrm{~Hz}), 8.55\left(1 \mathrm{H}, \mathrm{d}, \mathrm{C}_{5}-\mathrm{H}, J=7.8 \mathrm{~Hz}\right), 9.05(1 \mathrm{H}, \mathrm{s},-$ $\mathrm{NH}, \mathrm{D}_{2} \mathrm{O}$ exchangeable); ${ }^{13} \mathrm{C}$ NMR $\left(150 \mathrm{MHz}, \mathrm{CDCl}_{3}\right): \delta_{\mathrm{C}}$ $=14.22,21.40,25.05,30.94,44.47,46.04,59.49,61.80,112.48$, $118.40,119.99,135.86,150.07,151.19,161.94,168.48,178.11$, 207.09; MS ( $m / z): 358 \mathrm{M}^{+}$. (Found: C, 60.02; H, 6.43; N, 15.37 $\mathrm{C}_{18} \mathrm{H}_{22} \mathrm{~N}_{4} \mathrm{O}_{4}$ requires $\mathrm{C}, 60.32 ; \mathrm{H}, 6.19 ; \mathrm{N}, 15.63$.)

(3) 1-(2-(2,7-Dimethyl-1,8-naphthyridin-4-yloxy)acetyl)-3methyl-1H-pyrazol-5(4H)-one (5)

Method A: Silent Reaction. A mixture of acid hydrazide 1 $(16 \mathrm{mmol})$ with ethylacetoacetate $(65 \mathrm{mmol})$ was heated in steam bath for $3 \mathrm{~h}$; the mixture was left to cool to room temperature. The yellow precipitate so formed was collected by filtration, washed with pet. ether, and dried. Recrystallization, from ethanol, afforded compound $\mathbf{5}$.

Method B: Sonicated Reaction. A mixture of acid hydrazide 1 (16 mmol) and ethylacetoacetate $(65 \mathrm{mmol})$ in $50 \mathrm{~mL}$ Erlenmeyer flask was subjected to ultrasound irradiation for suitable time ( $c f$. Table 1) until the starting material was no longer detectable by TLC. All the reactions were kept at temperature $60-65^{\circ} \mathrm{C}$. The yellow precipitate so formed was filtered off and washed with pet. ether and finally recrystallized from ethanol to afford the corresponding 1-(2-(2,7-dimethyl-1,8-naphthyridin-4yloxy)acetyl)-3-methyl-1H-pyrazol-5(4H)-one 5, m.p. 194196. $2^{\circ}$ C. FTIR: $1604(\mathrm{C}=\mathrm{C}) ; 1620(\mathrm{C}=\mathrm{N}) ; 1625$ (C=O amidic); ${ }^{1} \mathrm{H}$ NMR $\left(600 \mathrm{MHz}, \mathrm{CDCl}_{3}\right): \delta_{\mathrm{H}}=2.17,2.43,2.60(9 \mathrm{H}$, $\left.3 \mathrm{~s}, 3 \mathrm{CH}_{3}\right), 3.39\left(2 \mathrm{H}, \mathrm{s}, \mathrm{CH}_{2}\right.$ of pyrazole $), 5.64(2 \mathrm{H}$, br.s, $\left.\mathrm{OCH}_{2} \mathrm{CO}\right), 6.26\left(1 \mathrm{H}, \mathrm{s}, \mathrm{C}_{3}-\mathrm{H}\right), 7.14\left(1 \mathrm{H}, \mathrm{d}, \mathrm{C}_{6}-\mathrm{H}, J=7.8 \mathrm{~Hz}\right)$, $8.53\left(1 \mathrm{H}, \mathrm{d}, \mathrm{C}_{5}-\mathrm{H}, J=7.8 \mathrm{~Hz}\right) ;{ }^{13} \mathrm{C} \mathrm{NMR}\left(150 \mathrm{MHz}, \mathrm{CDCl}_{3}\right): \delta_{\mathrm{C}}$ $=12.91,21.33,25.12,29.70,45.91,112.29,118.40,119.86,135.80$, $150.07,151.19,161.86,161.94,168.48,178.11,207.09$; MS $(m / z)$ : $312 \mathrm{M}^{+}$. (Found: C, 61.67; $\mathrm{H}, 5.03 ; \mathrm{N}, 17.64 \mathrm{C}_{16} \mathrm{H}_{16} \mathrm{~N}_{4} \mathrm{O}_{3}$ requires $\mathrm{C}, 61.53 ; \mathrm{H}, 5.16 ; \mathrm{N}, 17.94$.)

(4) 5-((2,7-Dimethyl-1,8-naphthyridin-4-yl)oxy)methyl)-1,3,4oxadiazole-2(3H)-thione (6)

Method A: Silent Reaction. The hydrazide 1 ( $2 \mathrm{mmol})$ was dissolved in hot ethanolic potassium hydroxide solution (0.11 gm KOH in $5.5 \mathrm{~mL}$ absolute ethanol). Carbon disulfide $(23 \mathrm{mmol})$ was added to the reaction mixture and heated under refluxed on water bath until the evolution of $\mathrm{H}_{2} \mathrm{~S}$ ceased. The reaction mixture was cooled and acidified with acetic acid. The formed solid precipitate was filtered off, washed with water, and recrystallized from methanol to give the title compound as off-white crystals.

Method B: Sonicated Reaction. A mixture of acid hydrazide 1 ( $2 \mathrm{mmol}$ ) was dissolved in hot ethanolic potassium hydroxide solution ( $0.11 \mathrm{gm} \mathrm{KOH}$ in $5.5 \mathrm{~mL}$ absolute ethanol) and carbon disulfide $(23 \mathrm{mmol})$ in $50 \mathrm{~mL}$ Erlenmeyer flask. The mixture was subjected to ultrasound irradiation for suitable time ( $c f$. Table 2) until the evolution of $\mathrm{H}_{2} \mathrm{~S}$ ceased and the starting material was no longer detectable by TLC. The reaction was kept at temperature $60-65^{\circ} \mathrm{C}$. The reaction mixture was cooled and acidified 
with acetic acid. The formed solid precipitate was filtered off, washed with water, and recrystallized from methanol to afford the corresponding 5-((2,7-dimethyl-1,8-naphthyridin4-yl)oxy)methyl)-1,3,4-oxadiazole-2(3H)-thione 6, m.p. 261$263^{\circ} \mathrm{C}$. FTIR: $1293(\mathrm{C}=\mathrm{S}), 1607(\mathrm{C}=\mathrm{N}), 3200(-\mathrm{NH})$; $\mathrm{MS}(\mathrm{m} / z)$ : $288 \mathrm{M}^{+}$. (Found: C, 54.53; H, 3.90; N, $19.20 \mathrm{C}_{13} \mathrm{H}_{12} \mathrm{~N}_{4} \mathrm{O}_{2} \mathrm{~S}$ requires $\mathrm{C}, 54.15 ; \mathrm{H}, 4.20 ; \mathrm{N}, 19.43$.)

(5) Potassium2-(2-(2,7-dimethyl-1,8-naphthyridin-4-yloxy) acetyl)hydrazinecarbodithioate ( 7 )

Method A: Silent Reaction. Carbon disulphide $(0.6 \mathrm{~mL}$, $10 \mathrm{mmol})$ was added dropwise to an ice cold solution of potassium hydroxide $(0.56 \mathrm{gm}, 10 \mathrm{mmol})$ in absolute ethanol $(20 \mathrm{~mL})$ containing the respective hydrazide 1 (2.46 gm, $10 \mathrm{mmol}$ ). The mixture was stirred at room temperature for $8 \mathrm{~h}$. The separated solid was filtered off and washed several times with ether. The product obtained in quantitative yield was employed in the next reactions without further purification.

Method B: Sonicated Reaction. Carbon disulphide $(0.6 \mathrm{~mL}$, $10 \mathrm{mmol}$ ) was added dropwise to an ice cold solution of potassium hydroxide $(0.56 \mathrm{gm}, 10 \mathrm{mmol})$ in absolute ethanol $(20 \mathrm{~mL})$ containing the respective hydrazide 1 (2.46 gm, $10 \mathrm{mmol})$. The mixture subjected to ultrasound irradiation at room temperature for a suitable time ( $c f$. Table 2$)$. The separated solid was filtered off, washed several time with ether, and dried. FTIR: 1686 (C=O amidic); 1291 (C=S); 3132 (N-H); (Found: C, 43.61; H, 3.33; N, $15.22 \mathrm{C}_{13} \mathrm{H}_{13} \mathrm{KN}_{4} \mathrm{O}_{2} \mathrm{~S}_{2}$ requires $\mathrm{C}, 43.31 ; \mathrm{H}, 3.63 ; \mathrm{N}, 15.54$.)

(6) 5-((2,7-Dimethyl-1,8-naphthyridin-4-yl)oxy)methyl)-1,3,4thiadiazole-2-thiol (8)

Method A: Silent Reaction. The potassium salt 7 (0.36 gm, $1 \mathrm{mmol})$ was added in small portions to $\mathrm{H}_{2} \mathrm{SO}_{4}(d=1.836$, $1.75 \mathrm{~mL}$ ) under gentle stirring at $0^{\circ} \mathrm{C}$. After complete addition of the salt the stirring was continued for further $2 \mathrm{~h}$; ; then the solution was poured into ice. The precipitate formed was filtered off, washed with water, dried, and recrystallized from ethanol to give the title compound as chestnut crystals.

Method B: Sonicated Reaction. The potassium salt 7 (0.36 gm, $1 \mathrm{mmol})$ was added in small portions to $\mathrm{H}_{2} \mathrm{SO}_{4}(d=1.836$, $1.75 \mathrm{~mL}$ ) in $50 \mathrm{~mL}$ Erlenmeyer flask under gentle stirring at $0^{\circ} \mathrm{C}$. After complete addition of the salt, the mixture was subjected to ultrasound irradiation at room temperature for suitable time ( $c f$. Table 2) until the starting material was no longer detectable by TLC. The solution was poured into ice. The precipitate formed was filtered off, washed with water, dried, and recrystallized from ethanol to afford the corresponding 5-((2,7-dimethyl-1,8-naphthyridin-4yl)oxy)methyl)-1,3,4-thiadiazole-2-thiol 8, m.p. $223-225^{\circ} \mathrm{C}$. FTIR: $1604(\mathrm{C}=\mathrm{C}) ; 1630(\mathrm{C}=\mathrm{N})$ and $2352(\mathrm{~S}-\mathrm{H}) ;{ }^{1} \mathrm{H}$ NMR $\left(600 \mathrm{MHz}, \mathrm{CDCl}_{3}: \mathrm{DMSO}_{6}\right): \delta_{\mathrm{H}}=2.40,2.61(6 \mathrm{H}, 2 \mathrm{~s}$, $\left.2 \mathrm{CH}_{3}\right), 5.79\left(2 \mathrm{H}, \mathrm{s},-\mathrm{CH}_{2}\right), 6.22\left(1 \mathrm{H}, \mathrm{s}, \mathrm{C}_{3}-\mathrm{H}\right), 7.5(1 \mathrm{H}, \mathrm{d}$, $\left.\mathrm{C}_{6}-\mathrm{H}, J=7.8 \mathrm{~Hz}\right), 8.50\left(1 \mathrm{H}, \mathrm{d}, \mathrm{C}_{5}-\mathrm{H}, J=7.8 \mathrm{~Hz}\right), 10.5(1 \mathrm{H}, \mathrm{s}$, S-H, $\mathrm{D}_{2} \mathrm{O}$ exchangeable), ${ }^{13} \mathrm{C}$ NMR (150 MHz, DMSO- $\left.\mathrm{d}_{6}\right)$ : $\delta_{\mathrm{C}}=24.52,25.33,43.28,111.89,118.00,120.33,135.36,144.51$,
152.27, 158.52, 161.86, 167, 188; MS $(m / z): 304 \mathrm{M}^{+}$. (Found: C, 51.63; $\mathrm{H}, 3.71 ; \mathrm{N}, 18.06 \mathrm{C}_{13} \mathrm{H}_{12} \mathrm{~N}_{4} \mathrm{OS}_{2}$ requires 51.30; $\mathrm{H}, 3.97$; $\mathrm{N}, 18.41$.

(7) Synthesis of 4-N-Substituted-5-((2,7-dimethyl-1,8-naphthyridin-4-yloxy)methyl)-4H-1,2,4-triazole-3-thiol (9a-c)

Method A: Silent Reaction. A mixture of the potassium salt 7 (0.51 gm, $1.3 \mathrm{mmol})$, appropriate hydrazine derivative (2.6 mmol), and water $(0.2 \mathrm{~mL})$ in $10 \mathrm{~mL}$ absolute ethanol was refluxed with stirring for a suitable time ( $c f$. Table 2 ) until the starting material was no longer detectable by TLC. The reaction mixture was cooled and the solid precipitate was filtered off, dried, and finally recrystallized from glacial acetic acid to give the title compounds $\mathbf{9 a}-\mathbf{c}$.

Method B: Sonicated Reaction. A mixture of the potassium salt 7 (0.51 gm, $1.3 \mathrm{mmol})$, appropriate hydrazine derivative $(2.6 \mathrm{mmol})$, and water $(0.2 \mathrm{~mL})$ in $10 \mathrm{~mL}$ absolute ethanol in $50 \mathrm{~mL}$ Erlenmeyer flask was subjected to ultrasound irradiation for suitable time ( $c f$. Table 2) until the starting material was no longer detectable by TLC. All the reactions were kept at temperature $60-65^{\circ} \mathrm{C}$ (the temperature inside reaction vessel was $60^{\circ} \mathrm{C}$ ). The reaction mixture was cooled and the solid precipitate was filtered off, dried, and finally recrystallized from glacial acetic acid to afford the corresponding 4-N-substitueted-5-((2,7-dimethyl-1,8naphthyridin-4-yloxy) methyl)-4H-1,2,4-triazole-3-thiol 9a-c.

The synthesized compounds $(\mathbf{9 a}-\mathbf{c})$ with their physical data are listed below.

4-Amino-5-((2,7-dimethyl-1,8-naphthyridin-4-yloxy)methyl)4H-1,2,4-triazole-3-thiol (9a). Brown crystals; m.p 286$288^{\circ}$ C. FTIR: $1601(\mathrm{C}=\mathrm{N}) ; 2363(\mathrm{~S}-\mathrm{H}) ; 3151,3244\left(-\mathrm{NH}_{2}\right) ;{ }^{1} \mathrm{H}$ $\operatorname{NMR}\left(600 \mathrm{MHz}, \mathrm{DMSO}-\mathrm{d}_{6}\right): \delta_{\mathrm{H}}=2.35,2.44\left(6 \mathrm{H}, 2 \mathrm{~s}, 2 \mathrm{CH}_{3}\right)$, $2.91\left(2 \mathrm{H}, \mathrm{s}, \mathrm{NH}_{2}, \mathrm{D}_{2} \mathrm{O}\right.$ exchangeable), $5.75\left(2 \mathrm{H}, \mathrm{s},-\mathrm{CH}_{2}\right)$, $6.15\left(1 \mathrm{H}, \mathrm{s}, \mathrm{C}_{3}-\mathrm{H}\right), 7.28\left(1 \mathrm{H}, \mathrm{d},-\mathrm{CH}_{2}, J=7.8 \mathrm{~Hz}\right), 8.33(1 \mathrm{H}, \mathrm{d}$, $\left.\mathrm{C}_{5}-\mathrm{H}, J=7.8 \mathrm{~Hz}\right)$ and $13.55\left(1 \mathrm{H}, \mathrm{s}, \mathrm{S}-\mathrm{H}, \mathrm{D}_{2} \mathrm{O}\right.$ exchangeable); ${ }^{13} \mathrm{C}$ NMR $\left(150 \mathrm{MHz}, \mathrm{DMSO}-\mathrm{d}_{6}\right): \delta_{\mathrm{C}}=20.58,24.62,51.25$, $111.55,117.92,120.01,135.24,148.82,149.70,152.86,161.81$, 166.74, 176.30; MS $(\mathrm{m} / z)$ : $302 \mathrm{M}^{+}$. (Found: C, 51.84; H, 4.86; $\mathrm{N}, 27.86 \mathrm{C}_{13} \mathrm{H}_{14} \mathrm{~N}_{6} \mathrm{OS}$ requires $\mathrm{C}, 51.64 ; \mathrm{H}, 4.67 ; \mathrm{N}, 27.80$.)

5-((2,7-Dimethyl-1,8-naphthyridin-4-yloxy)methyl)-4-(phenylamino)-4H-1,2,4-triazole-3-thiol (9b). Yellow crystals; m.p 221.6-222.9 ${ }^{\circ}$ C. FTIR: $1293(\mathrm{C}=\mathrm{S}), 1605(\mathrm{C}=\mathrm{N}), 2363(\mathrm{~S}-\mathrm{H})$, $3649(\mathrm{~N}-\mathrm{H}) ;{ }^{1} \mathrm{H}$ NMR $\left(600 \mathrm{MHz}, \mathrm{CDCl}_{3}: \mathrm{DMSO}_{6}\right)$ : $\delta_{\mathrm{H}}=2.57,3.12\left(6 \mathrm{H}, 2 \mathrm{~s}, 2 \mathrm{CH}_{2}\right) ; 2.69\left(1 \mathrm{H}, \mathrm{s},-\mathrm{NHPh}, \mathrm{D}_{2} \mathrm{O}\right.$ exchangeable), $5.81\left(2 \mathrm{H}, \mathrm{s},-\mathrm{CH}_{2}\right), 6.22\left(1 \mathrm{H}, \mathrm{s}, \mathrm{C}_{3}-\mathrm{H}\right) ; 7.23$, $7.41(6 \mathrm{H}, \mathrm{m}, \mathrm{PhH}$ 's and $\mathrm{S}-\mathrm{H}), 7.6\left(1 \mathrm{H}, \mathrm{d}, \mathrm{C}_{6}-\mathrm{H}, J=7.8 \mathrm{~Hz}\right)$; $8.48\left(1 \mathrm{H}, \mathrm{d}, \mathrm{C}_{5}-\mathrm{H}, J=7.8 \mathrm{~Hz}\right)$; MS $(\mathrm{m} / z): 302 \mathrm{M}^{+}$. (Found: $\mathrm{C}$, $60.65 ; \mathrm{H}, 4.32 ; \mathrm{N}, 22.63 \mathrm{C}_{19} \mathrm{H}_{18} \mathrm{~N}_{6}$ OS requires $\mathrm{C}, 60.30 ; \mathrm{H}$, 4.79; N, 22.21.)

5-((2,7-Dimethyl-1,8-naphthyridin-4-yloxy)methyl)-4-(methylamino)-4H-1,2,4-triazole-3-thiol (9c). Yellow crystals; m.p 233-235 C. FTIR: $1602(\mathrm{C}=\mathrm{N}), 2364(\mathrm{~S}-\mathrm{H}), 3280$ $(\mathrm{N}-\mathrm{H}) ;{ }^{1} \mathrm{H}$ NMR $\left(600 \mathrm{MHz}, \mathrm{CDCl}_{3}: \mathrm{DMSO}_{-} \mathrm{d}_{6}\right): \delta_{\mathrm{H}}=2.07$ 
$\left(3 \mathrm{H}, \mathrm{s},-\mathrm{NHCH}_{3}\right), 2.45,2.56\left(6 \mathrm{H}, 2 \mathrm{~s}, 2 \mathrm{CH}_{3}\right), 3.5(1 \mathrm{H}, \mathrm{s},-\mathrm{NH}$, $\mathrm{D}_{2} \mathrm{O}$ exchangeable), $5.79\left(2 \mathrm{H}, \mathrm{s},-\mathrm{CH}_{2}\right), 6.16\left(1 \mathrm{H}, \mathrm{s}, \mathrm{C}_{3}-\mathrm{H}\right)$, $7.27\left(1 \mathrm{H}, \mathrm{d}, \mathrm{C}_{6}-\mathrm{H}, J=7.8 \mathrm{~Hz}\right), 8.35\left(1 \mathrm{H}, \mathrm{d}, \mathrm{C}_{5}-\mathrm{H}, J=7.8 \mathrm{~Hz}\right)$, $10.27(1 \mathrm{H}, \mathrm{s},-\mathrm{SH}) ;{ }^{13} \mathrm{C}$ NMR $\left(150 \mathrm{MHz}, \mathrm{DMSO}-\mathrm{d}_{6}\right): \delta_{\mathrm{C}}=$ $21.25,24.71,30.74,36.93,111.15,117.84,120.05,135.28,147.87$, $150.08,152.80,161.40,166.29,176$; MS $(\mathrm{m} / z): 316 \mathrm{M}^{+}$. (Found: C, 53.45; $\mathrm{H}, 4.86 ; \mathrm{N}, 26.39 \mathrm{C}_{14} \mathrm{H}_{16} \mathrm{~N}_{6} \mathrm{OS}$ requires 53.15; $\mathrm{H}$, $5.10 ; \mathrm{N}, 26.56$.

\subsection{Cytotoxicity}

Measurement of Potential Cytotoxicity by SRB Assay. The selected 1,8-naphthyridine derivatives, compounds (3a, 3b, 5, $6,8,9 a, 9 b$, and $9 c$ ), were subjected to a screening system for evaluation of their antitumor activity against liver HepG2 cancer cell line in comparison to the known anticancer drugs, doxorubicin (DOX). Potential cytotoxicity of the selected 1,8-naphthyridine derivatives was tested using the method of Skehan et al. [31] as follows: cells were plated in 96multiwell plate $\left(10^{4}\right.$ cells/well) for $24 \mathrm{~h}$ before treatment with compounds to allow attachment of cell to the wall of the plate. Different concentrations of the compound under test $(5,12.5,25$, and $50 \mu \mathrm{g} / \mathrm{mL})$ were added to the cell monolayer. Triplicate wells were prepared for each individual dose. Monolayer cells were incubated with the compounds for 48 $\mathrm{h}$ at $37^{\circ} \mathrm{C}$ and in atmosphere of $5 \% \mathrm{CO}_{2}$. Cultures were fixed with trichloroacetic acid and stained for $30 \mathrm{~min}$ with $0.4 \%(\mathrm{wt} / \mathrm{vol}$ ) sulforhodamine B (SRB) dissolved in $1 \%$ acetic acid. Unbound dye was removed by four washes with $1 \%$ acetic acid, and protein-bound dye was extracted with $10 \mu \mathrm{M}$ unbuffered Tris base [tris(hydroxymethyl) aminomethane] for determination of optical density in a computer-interfaced, 96-well microtiter plate reader. The SRB assay results were linear with the number of cells and with values for cellular protein measured by both the Lowry and Bradford assays at densities ranging from sparse subconfluence to multilayered supraconfluence. The signal-to-noise ratio at $564 \mathrm{~nm}$ was approximately 1.5 with 1,000 cells per well. The relation between surviving fraction and drug concentration is plotted to get the survival curve of both cancer cell lines after the specified compound.

\section{Conflict of Interests}

The authors declare that they have no conflict of interests regarding the publication of this paper.

\section{References}

[1] S. Massari, D. Daelemans, M. L. Barreca et al., "A 1,8naphthyridone derivative targets the HIV-1 Tat-mediated transcription and potently inhibits the HIV-1 replication," Journal of Medicinal Chemistry, vol. 53, no. 2, pp. 641-648, 2010.

[2] A. A. Fadda, A. M. El-Defrawy, and S. A. El-Habiby, "Synthesis, cytotoxicity activity, DFT molecular modeling studies and quantitative structure activity relationship of some novel 1, 8naphthyridine derivatives," The American Journal of Organic Chemistry, vol. 2, no. 4, pp. 87-96, 2012.
[3] G. Roma and G. Grossi, "1, 8-naphthyridines VII. New substituted 5-amino[1, 2, 4] triazolo[4, 3-a] [1, 8]naphthyridine-6carboxamides and their isosteric analogues, exhibiting notable anti-inflammatory and/or analgesic activities, but no acute gastrolesivity," European Journal of Medicinal Chemistry, vol. 43, no. 8, pp. 1665-1680, 2008.

[4] S. Olepu and P. K. Suryadevara, "2-Oxo-tetrahydro-1, 8naphthyridines as selective inhibitors of malarial protein farnesyltransferase and as anti-malarials," Bioorganic and Medicinal Chemistry Letters, vol. 18, no. 2, pp. 494-497, 2008.

[5] E. Laxminarayana, T. Karunakar, S. S. Shankar, and M. T. Chary, "A study on antibacterial activity of substituted 1, 8-naphthyridines containing carbaldehydes, methyleden hydrazines, thiadiazolamines and triazolethiols," Advanced Drug Delivery Reviews, vol. 2, no. 2, pp. 6-11, 2012.

[6] J. M. Quintela and C. Peinador, "Piperazine N-substituted naphthyridines, pyridothienopyrimidines and pyridothienotriazines: new antiprotozoals active against Philasterides dicentrarchi," European Journal of Medicinal Chemistry, vol. 38, no. 3, pp. 265-275, 2003.

[7] T. Aboul-Fadl, F. A. S. Bin-Jubair, and O. Aboul-Wafa, "Schiff bases of indoline-2,3-dione (isatin) derivatives and nalidixic acid carbohydrazide, synthesis, antitubercular activity and pharmacophoric model building," European Journal of Medicinal Chemistry, vol. 45, no. 10, pp. 4578-4586, 2010.

[8] P. L. Ferrarini, C. Mori, M. Badawneh et al., "Synthesis and antiplatelet activity of some 3-phenyl-1, 8-naphthyridine derivatives," Farmaco, vol. 55, no. 9-10, pp. 603-610, 2000.

[9] V. Kren and T. Renzanak, "Sweet antibiotics: the role of glycosidic residues in antibiotic and antitumor activity and their randomization," FEMS Microbiology Reviews, vol. 32, no. 5, pp. 858-889, 2008.

[10] V. Kren and L. Martínková, "Glycosides in medicine: the role of glycosidic residue in biological activity," Medicinal Chemistry Reviews, vol. 8, pp. 1313-1338, 2001.

[11] Y. Tsuzuki, K. Tomita, K. Shbamori, Y. Sato, S. Kashimoto, and K. Chiba, "Synthesis and Ssructure-activity relationships of novel 7-substituted 1, 4-dihydro-4-oxo-1-(2-thiazolyl)-1, 8naphthyridine-3-carboxylic acids as antitumor agents. Part 2," Journal of Medicinal Chemistry, vol. 47, no. 8, pp. 2097-2109, 2004.

[12] D. A. Burden and N. Oshereoff, "Mechanism of action of eukaryotic topoisomerase II and drugs targeted to the enzyme," Biochimica et Biophysica Acta, vol. 1400, no. 1-3, pp. 139-154, 1998.

[13] A. F. Eweas, N. M. Khalifa, N. S. Ismail, I. M. A. Al-Omar, and A. M. Soliman, "Synthesis, molecular docking of novel 1, 8-naphthyridine derivatives and their cytotoxic activity against HepG2 cell lines," Medicinal Chemistry Research, vol. 23, no. 1, pp. 76-86, 2014.

[14] A. M. Farag, A. S. Mayhoub, S. E. Barakat, and A. H. Bayomi, "Regioselective synthesis and antitumor screening of some novel N-phenylpyrazole derivatives," Bioorganic and Medicinal Chemistry, vol. 16, no. 2, pp. 881-889, 2008.

[15] S. Huang, R. Lin, Y. Yu et al., "Synthesis of 3-(1H-benzimidazol2-yl)-5-isoquinolin-4-ylpyrazolo[1, 2-b $]$ pyridine, a potent cyclin dependent kinase 1 (CDK1) inhibitor," Bioorganic and Medicinal Chemistry Letters, vol. 17, no. 5, pp. 1243-1245, 2007.

[16] W. Rzeski, J. Matysiak, and M. Kandefer-Szerszen, "Anticancer, neuroprotective activities and computational studies of 2amino-1, 3, 4-thiadiazole based compound," Bioorganic and Medicinal Chemistry, vol. 15, no. 9, pp. 3201-3207, 2007. 
[17] J.-Y. Chou, S.-Y. Lai, S.-L. Pan, G.-M. Jow, J.-W. Chern, and J.H. Guh, "Investigation of anticancer mechanism of thiadiazolebased compound in human non-small cell lung cancer A549 cells," Biochemical Pharmacology, vol. 66, no. 1, pp. 115-124, 2003.

[18] M. R. Yadav, S. T. Shirude, D. S. Puntambekar et al., "Studies in 3,4-diaryl-1,2,5-oxadiazoles and their N-oxides: search for better COX-2 inhibitors," Acta Pharmaceutica, vol. 57, no. 1, pp. 13-30, 2007.

[19] G. Cravotto and P. Cintas, "Power ultrasound in organic synthesis: moving cavitational chemistry from academia to innovative and large-scale applications," Chemical Society Reviews, vol. 35, pp. 180-196, 2006.

[20] L. Pizzuti, P. L. G. Martins, B. A. Ribeiro et al., "Efficient sonochemical synthesis of novel 3,5-diaryl-4,5-dihydro- $1 \mathrm{H}$ pyrazole-1-carboximidamides," Ultrasonics Sonochemistry, vol. 17, no. 1, pp. 34-37, 2010.

[21] Z. Fu and H. Shao, "An efficient synthesis of 3-substituted indole derivates under ultrasound irradiation," Ultrasonics Sonochemistry, vol. 18, no. 2, pp. 520-526, 2011.

[22] Q. Liu, H. Ai, and Z. Li, "Potassium sorbate as an efficient and green catalyst for Knoevenagel condensation," Ultrasonics Sonochemistry, vol. 18, no. 2, pp. 477-479, 2011.

[23] K. Jadidi, R. Gharemanzadeh, M. Mehrdad, H. R. Darabi, H. R. Khavasi, and D. Asgari, "A facile synthesis of novel pyrrolizidines under classical and ultrasonic conditions," Ultrasonics Sonochemistry, vol. 15, no. 2, pp. 124-128, 2008.

[24] M. R. Shaaban, T. S. Saleh, A. S. Mayhoub, and A. M. Farag, "Single step synthesis of new fused pyrimidine derivatives and their evaluation as potent Aurora-A kinase inhibitors," European Journal of Medicinal Chemistry, vol. 46, no. 9, pp. 3690-3695, 2011.

[25] M. Mokhtar, T. S. Saleh, N. S. Ahmed, S. A. Al-Thabaiti, and R. A. Al-Shareef, "An eco-friendly N-sulfonylation of amines using stable and reusable $\mathrm{Zn}$-Al-hydrotalcite solid base catalyst under ultrasound irradiation," Ultrasonics Sonochemistry, vol. 18, no. 1, pp. 172-176, 2011.

[26] N. S. Ahmed, T. S. Saleh, and E. H. El-Mossalamy, "An efficiently sonochemical synthesis of novel pyrazoles, bipyrazoles and pyrazol-3- ylPyrazolo[3,4-d]pyrimidines incorporating 1H-benzoimidazole Moiety," Current Organic Chemistry, vol. 17, pp. 194-202, 2013.

[27] N. S. Ahmed, K. O. Alfooty, and S. S. Khalifah, "An efficient sonochemical synthesis of novel Schiff's bases, thiazolidine and Pyrazolidine Incorporating 1, 8-NaphthyridineMoiety and their cytotoxic activity against HePG2 cell lines," Scientific World Journal, vol. 2014, Article ID 587059, 10 pages, 2014.

[28] N. Cabello, P. Cintas, and J. L. Luche, "sonochemical effects in the additions of furan to masked Ortho benzoquinone," Ultrasonics Sonochemistry, vol. 10, no. 1, pp. 25-31.

[29] K. Ikawa, F. Takami, Y. Fukui, and K. Tokuyama, "A novel reagent for the vilsmeier-haack reaction," Tetrahedron Letters, vol. 10, no. 38, pp. 3279-3281, 1969.

[30] W. S. El-Hamouly, K. M. Amin, S. A. El-Assaly, and E. A. A. El-Meguid, "Synthesis and antitumor activity of some new Nsubstituted-sulfonyl, 1,2,4-triazole, $\mathrm{N}$-substituted-benzylidene and pyrrole derivatives attached to 4-(benzo[d]thiazol-2yl)benzohydrazide," Der Pharma Chemica, vol. 3, no. 6, pp. 293306, 2011.

[31] P. Skehan, R. Storeng, D. Scudiero et al., "New colorimetric cytotoxicity assay for anticancer-drug screening," Journal of the National Cancer Institute, vol. 82, no. 13, pp. 1107-1112, 1990. 

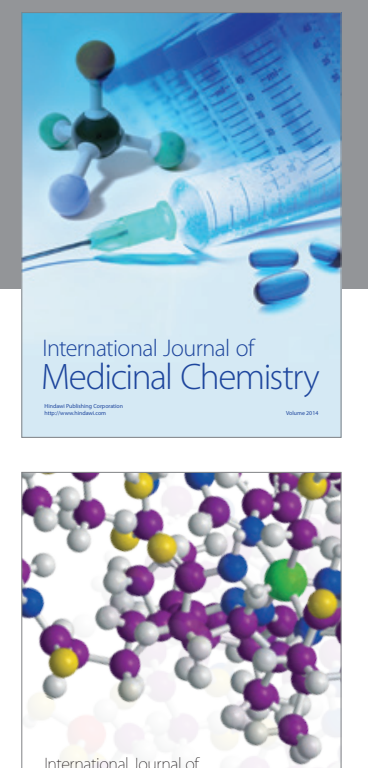

\section{Carbohydrate} Chemistry

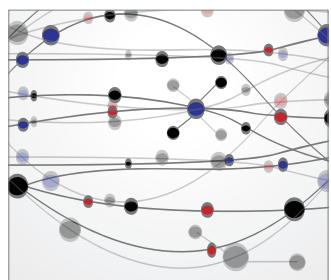

The Scientific World Journal
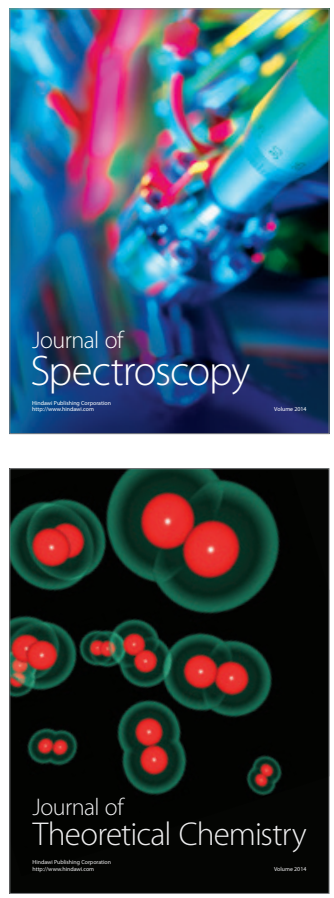
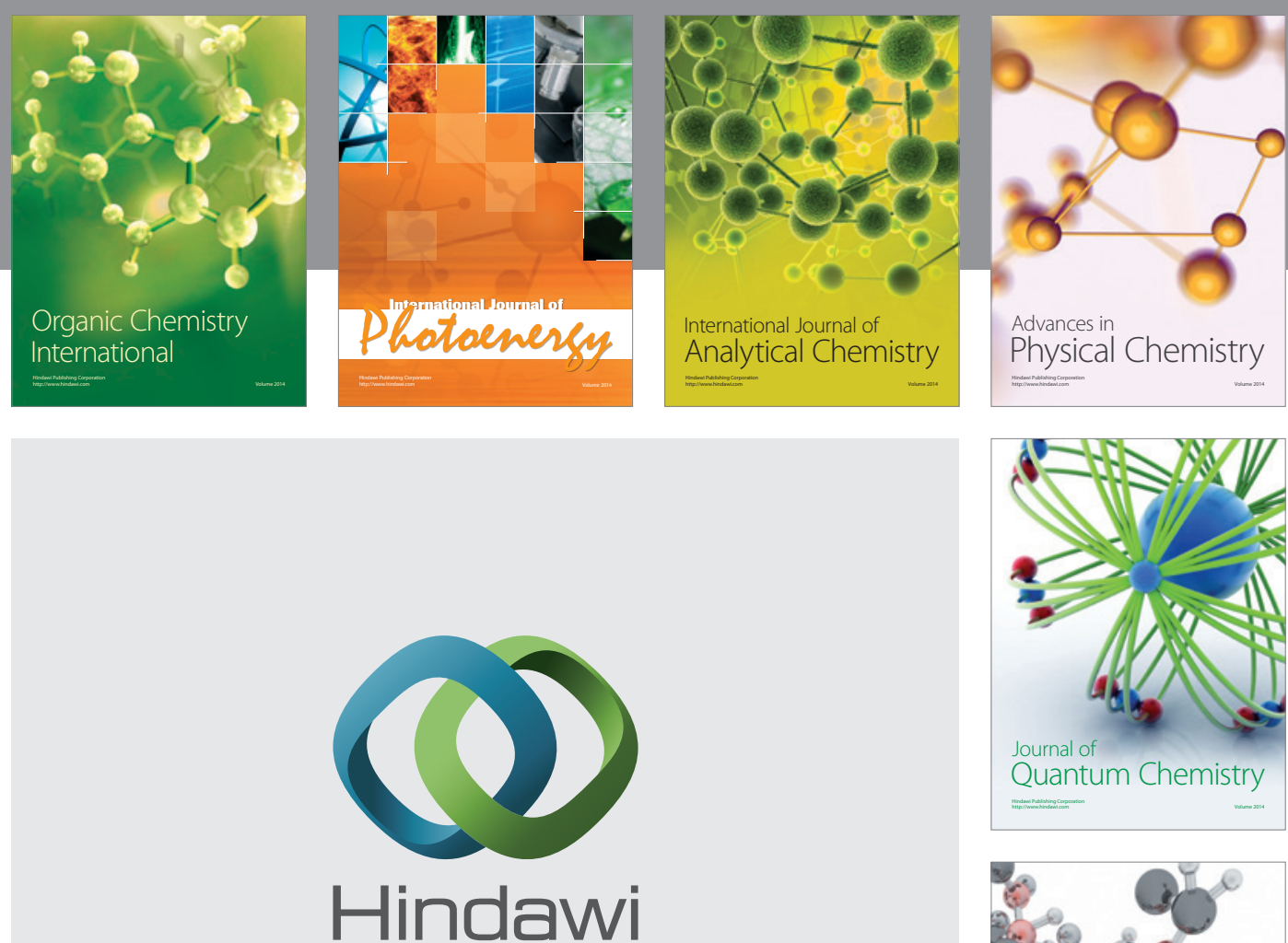

Submit your manuscripts at

http://www.hindawi.com

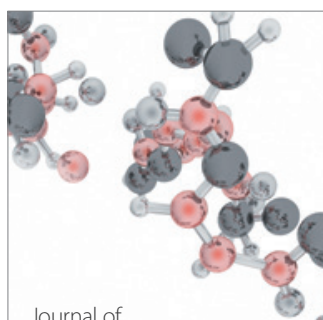

Analytical Methods

in Chemistry

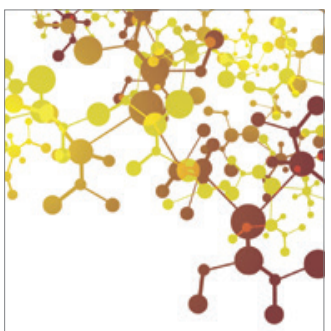

Journal of

Applied Chemistry

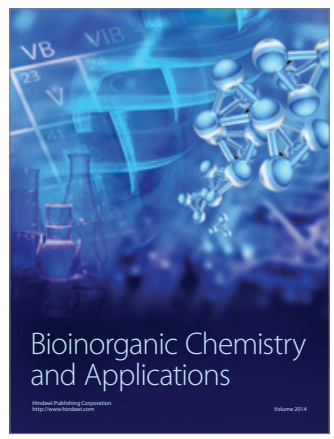

Inorganic Chemistry
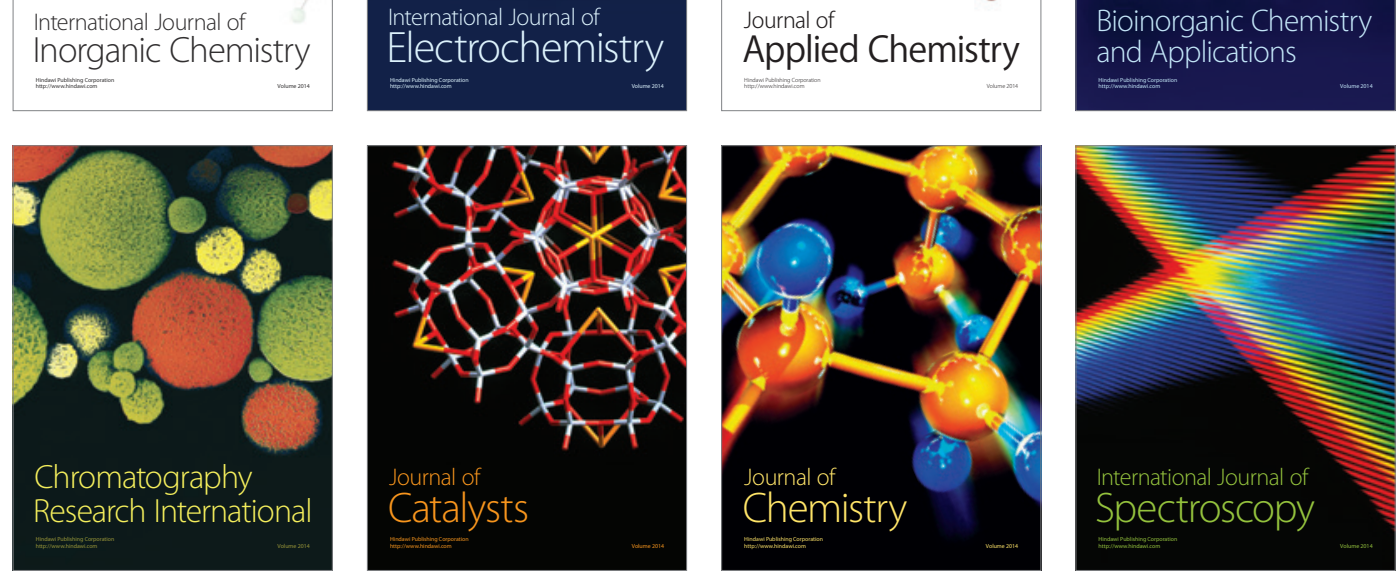